\title{
STORAGE STABILITY OF CASHEW APPLE JUICE PRESERVED BY HOT FILL AND ASEPTIC PROCESSES ${ }^{1}$
}

\author{
Maria Cecília Oliveira COSTA ${ }^{2}$, Geraldo Arraes MAIA ${ }^{2, *}$, Raimundo Wilane de FIGUEIREDO ${ }^{2}$, \\ Men de Sá Moreira de SOUZA FILHO ${ }^{3}$, Isabella Montenegro BRASIL ${ }^{2}$
}

\section{SUMMARY}

Cashew (Anacardium occidentale L.) apples from Pacajus, Ceará State, Brazil, were processed into high pulp content juice. The juice was packed either by hot fill or an aseptic process and evaluated for physical, physical-chemical, and sensorial changes during a 12-month storage period at room temperature. The results indicated that $\mathrm{pH}$, soluble solids, total acidity, total sugar content and color did not change significantly during storage nor were affected by the type of filling. The sensorial analysis showed that juice acceptance remained high throughout the storage period regardless of the filling system. Differences in juice viscosity persisted between both processes.

Keywords: cashew apple juice; storage; processing.

\section{RESUMO}

ESTABILIDADE DO SUCO DE CAJU PRESERVADO PELO MÉTODO “HOT FILL” E PROCESSO ASSÉPTICO. Pedúnculos de caju (Anacardium occidentale L.) de Pacajus, Estado do Ceará, Brasil, foram processados na forma de suco com alto teor de polpa. O suco foi acondicionado através do processo hot fill ou asséptico e verificada as alterações fisicas, fisico-quimicas e sensoriais durante armazenagem por doze meses à temperatura ambiente. Os resultados indicaram que pH, sólidos solúveis, acidez total, conteúdo de açúcar e cor não mudaram de modo significativo durante a armazenagem nem foram afetadas pelo modo de acondicionamento. Análise sensorial mostrou que a aceitação do suco foi mantida alta durante o periodo de armazenagem a despeito do sistema de enchimento. Diferenças na viscosidade dos sucos persistiram entre ambos processos.

Palavras-chave: suco de caju; armazenamento; processamento.

\section{1 - INTRODUCTION}

The world fruit juice market has reached a dynamic growth, which is expected to prevail also in the XXI century. The statistics has shown that beverages fruit blends, among others, is a growing section of the beverage market, which has called the attention of fruit growers and processors to attend the demand.

On the other hand, fruit juice distributors are making a profit over the increasing demand not only for pulpy juices, but also for fruit-juice blends. Recently, fruits considered as exotic are now gaining more and more space in the fruit juice market [18].

According to BRACO [3] the fruit juice segment is of great importance and the cashew apple juice presents a great potential for both national and international juice market. However, problems such as darkness of the juice, loss of vitamin $\mathrm{C}$, and sedimentation of pulp particles during storage has been seen as a barrier by the processing industries. Considering that the cashew apple can only be harvested during a four month period, it is of a great importance the use of technologies that make the product available during the whole year.

This work aims to study the chemical, physicalchemical, and sensorial changes during 12 month storage of high pulp content cashew apple juice, packed either

1. Recebido para publicação em 24/05/2002. Aceito para publicação em 07/08/2003 (000832).

${ }^{2}$ Department of Food Technology, University of Ceará. Campus do Pici. Cx, Postal 60356-000. Fortaleza, Ceará, Brazil.

${ }^{3}$ EMBRAPA - Tropical Agroindustry. CEP 60511-110. Fortaleza, Ceará, Brazil.

* A quem a correspondência deve ser enviada. in $500 \mathrm{~mL}$ glass bottle (hot fill bottling), or $500 \mathrm{~mL}$ tetra brik cartoon (aseptic filling).

\section{2 - MATERIAL AND METHODS}

Fresh cashew apples (Anacardium occidentale L.) were used for the processing of the juice (Figure 1).

The cashew apples with nuts were manually harvested, nuts detached and apples carefully placed in $10 \mathrm{~kg}$ plastic boxes and then transported to the processing facilities. Upon arrival, cashew apples were weighted, washed with running water and sorted for damage and then mashed in a fruit extractor where vapor was applied to avoid enzyme activity. The pulp was pressed and passed through a finisher and the obtained juice was transferred to a tank and them homogenized (100 Atm). Followed this treatment, the juice was deaerated $(600 \mathrm{~mm} \mathrm{Hg})$ and then heated in a heat exchanger at $90^{\circ} \mathrm{C}$ for 60 seconds. This heat treatment was followed by immediate bottling $\left(85^{\circ} \mathrm{C}\right)$ of the juice in glass bottles, which were immediately closed passed through a cooling tunnel and allowed to cool down at room temperature. After cooling, bottles were stored in card board boxes for further analysis. For the aseptic process, the procedures were the same as that of hot fill process up to the heat treatment, when the juice was cooled down, immediately, at the heat exchanger to $25^{\circ} \mathrm{C}$ and packed in $500 \mathrm{~mL}$, tetra brik cartoons in a aseptic filling machine. After packing, cartoons were placed in cardboard boxes and stored at room temperature for analysis, which were carried out immediately after packing and at every 30 days throughout storage period (12 months) for the juices obtained by either process.

The $\mathrm{pH}$ was determined with a Digimed $\mathrm{pH}$ meter. 
The total soluble solids (TSS) $\left({ }^{\circ}\right.$ Brix) using digital ATAGO refractometer with temperature compensation; the titratable acidity (TA) as citric acid and malic acid, as well as sugar content (TS) (\%) were measured according to the methods recommended by INSTITUTO ADOLFO LUTZ [9]; vitamin C content was determined according to the method recommended by PEARSON [14]; $\mathrm{SO}_{2}$ was quantitated according to AOAC [2]; Viscosity (V) was determined at $22^{\circ} \mathrm{C}$ with a BROOKFIELD viscometer Factor Finder and color by the use of a spectophotometer SPECTRONIC 20 - BAUSCH and LOMB according to MAIA, OLIVEIRA \& TELLES [10]; tannins (T) were quantitated according to FOLLIN DENIS as described in AOAC [2]; sensory evaluation was carried out by hedonic scale composed of nine points, where 9 means "extremely like it" and 1 means "extremely dislike it" $[11,16]$. The test was carried out in the morning period (9:00 to $11: 30 \mathrm{AM})$. The juice served to the panelists was diluted in water [4], approximately $30 \mathrm{~mL}$ of a 7 -fold dilution and sweetened with sugar.

Analyses of variance for physical and physicalchemicals determinations were performed using SOFT PRIMER OF BIOSTATISTICS [7]. Sensory evaluation was calculated with SAS [15].

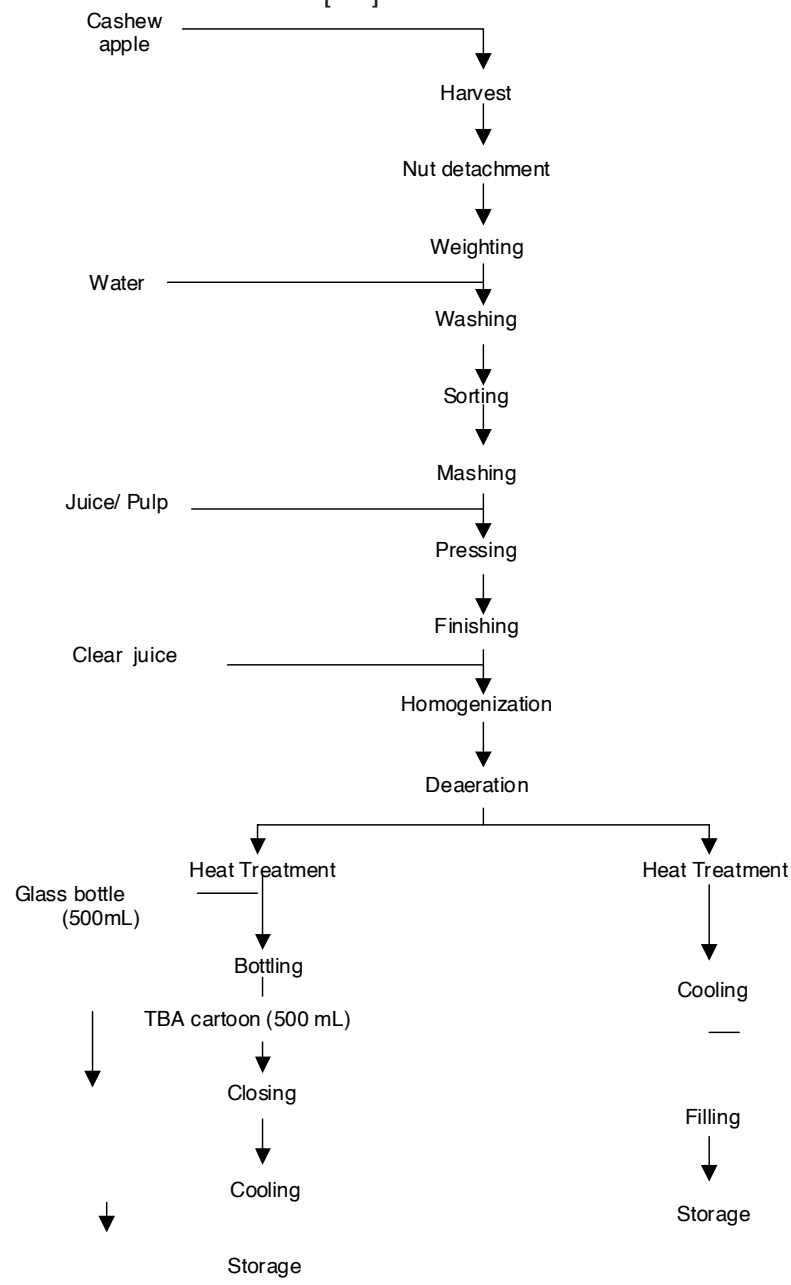

FIGURE 1. Flow sheet for processing of high pulp content cashew apple juice preserved by hot fill and aseptic process.

\section{3 - RESULTS AND DISCUSSION}

The results of chemical and physical-chemical evaluations are as shown in Table 1. No significant difference in $\mathrm{pH}$, at the $5 \%$ level, was observed between time zero and 350 days for the hot fill process. Analysis of variance did not show significant statistics difference between the average of $\mathrm{pH}$ of juice obtained by either process.

Soluble solids did not vary according to type of filling process. In fact, the variations found throughout storage time were not significant for either process or may have been caused by irrelevant factors.

No significant difference in titratable acidity was found for either filling process between initial and final time at the $5 \%$ level (Table 1) nor the type of process affected the acidity of the juice samples $(\mathrm{F}<1)$.

Samples obtained through the hot fill process showed a higher variation on sugar content as compared to those obtained through the aseptic process when storage times were evaluated (Table 1). Total sugar loss comprised 4.56 and $4.21 \%$ for the hot fill and aseptic process, respectively, after 350 days of storage. The type of filling process did not affect total sugar content significantly over storage time $(\mathrm{F}<1)$. The loss of total sugars may be explained by non enzymatic browning reactions.

The vitamin $\mathrm{C}$ content decreased toward the end of storage time for both processes. When initial and final times were compared, the loss of vitamin C was of 25.65 and $26.74 \%$ for the hot fill and aseptic bottling, respectively. The type of filling did not affect juice samples $(\mathrm{F}=0,11)$.

Over all, the aseptic process showed less variation on vitamin $\mathrm{C}$ throughout storage time when compared to the hot fill bottling. NAIR et al. [12] observed loss of $29-59 \%$ of ascorbic acid in cashew apple juice and in its blends at the end of 32 weeks at room temperature storage. SOUZA FILHO [17] found loss of $10,11 \%$ in cashew apple juice after 120 days in storage, also at room temperature. OLIVA, MENEZES \& FERREIRA [13] studing the stability of acerola nectar, obtained with two different processes, found that samples stored for 180 days at room temperature presented loss of ascorbic acid ca. $27 \%$ for spin cooker and hot fill bottling. The loss of vitamin $\mathrm{C}$ is an oxidative reaction which occur in fruit juice during storage and is highly dependent on the presence of oxygen in the head space or dissolved in the juice and the processing temperature.

According to the results obtained for water soluble pigments presented in Table 1, it is possible to observe that significant variations on storage time occurred more often on samples obtained through the aseptic process, even though no significant difference, $p<0,05$, was found when initial and final times were compared for either process. According to CURL \& TALBURT [5], the retention of pigments in their original form in fruit juices is important not only for visual appearance and acceptance, but also for the physiological aspect since some of these compounds such as carotenoids ( $\alpha$ e $\beta$-caroteno and criptoxantinas) and flavonoides are nutritionally important. 
TABLE 1. Chemical and physical-chemical changes on cashew apple juice with high pulp content preserved by hot fill and aseptic processes.

\begin{tabular}{|c|c|c|c|c|c|c|c|c|c|c|c|c|c|c|c|c|c|c|}
\hline $\begin{array}{l}\text { Analyses } \\
\text { / Storage } \\
\text { time }\end{array}$ & \multicolumn{2}{|c|}{$\mathrm{pH}$} & \multicolumn{2}{|c|}{$\begin{array}{c}\mathrm{SS} \\
\left({ }^{\circ} \mathrm{BRIX}\right)\end{array}$} & \multicolumn{2}{|c|}{$\mathrm{TA}(\mathrm{mg} / 100 \mathrm{~g})$} & \multicolumn{2}{|c|}{$\mathrm{TS}(\mathrm{mg} / 100 \mathrm{~g})$} & \multicolumn{2}{|c|}{$\begin{array}{c}\text { VIT. C } \\
(\mathrm{mg} / 100 \mathrm{~mL})\end{array}$} & \multicolumn{2}{|c|}{$\begin{array}{c}\text { WSP } \\
(\% \text { transm } \\
. / 420 \mathrm{~nm}) \\
\end{array}$} & \multicolumn{2}{|c|}{$\mathrm{SO}_{2}(\mathrm{ppm})$} & \multicolumn{2}{|c|}{$\mathrm{T}(\mathrm{mg} / 100 \mathrm{~g})$} & \multicolumn{2}{|c|}{$\mathrm{V}(\mathrm{cps})$} \\
\hline 0 & $3,62 \mathrm{ab}$ & $3,65 b$ & 11,0 & 11,0 & $0,76_{a b}$ & $0,76_{a b}$ & $0,80_{a b}$ & $0,80_{a}$ & $9,22 \mathrm{a}$ & $9,27 \mathrm{a}$ & $94,6 \mathrm{~b}$ & $96,0_{\mathrm{ce}}$ & $235,09_{a}$ & $254,78_{a}$ & $254,58_{b}$ & $239,51_{b}$ & $51,00_{a}$ & $46,000_{a}$ \\
\hline 10 & $3,64 \mathrm{bc}$ & $3,61 \mathrm{a}$ & 11,0 & 11,0 & $0,75 \mathrm{ab}$ & $0,75_{a b}$ & $0,78_{\mathrm{ab}}$ & $0,79_{a}$ & $8,99_{\mathrm{acd}}$ & $9,03 \mathrm{a}$ & $94,5 \mathrm{~b}$ & $94,6_{\mathrm{ae}}$ & $199,20_{b}$ & $208,37_{b}$ & $157,69_{a}$ & $153,51_{a}$ & $47,67 \mathrm{a}$ & $44,33 \mathrm{ab}$ \\
\hline 100 & 3,57 a & $3,57 \mathrm{a}$ & 11,2 & 11,2 & $0,78 \mathrm{a}$ & $0,78 \mathrm{a}$ & $0,8_{b}$ & $0,77_{\mathrm{a}}$ & $9,06_{\mathrm{ac}}$ & $8,74 b$ & $93,0_{b}$ & 91,8 bd & 104,39 aef & $106,80_{a}$ & $170,25 a$ & $167,46_{a}$ & $48,67 \mathrm{a}$ & $41,00 \mathrm{ab}$ \\
\hline 150 & - & - & 11,4 & 11,4 & $0,76_{a b}$ & $0,74 \mathrm{ab}$ & $0,8_{b}$ & $0,79 a$ & $8,87_{\mathrm{bcd}}$ & $8,85_{a b}$ & $87,0_{a}$ & $88,0_{A}$ & $97,63 \mathrm{ab}$ & $109,35 b$ & $297,62_{b}$ & $257,18_{b}$ & $48,67_{a}$ & $44,00 \mathrm{ab}$ \\
\hline 200 & $3,66_{b}$ & $3,66_{b}$ & 11,2 & 11,2 & $0,77_{\mathrm{ac}}$ & $0,76_{\mathrm{ab}}$ & $0,8_{b}$ & $0,80_{a}$ & $8,59 b$ & $8,50 \mathrm{~b}$ & $92,5_{a b}$ & $93,0 \mathrm{abd}$ & $88,33 \mathrm{bc}$ & $100,62 \mathrm{ab}$ & $264,15_{b}$ & $264,15_{b}$ & $46,67_{\mathrm{a}}$ & $39,53 \mathrm{bc}$ \\
\hline 250 & $3,63 b c$ & $3,61 \mathrm{a}$ & 11,1 & 11,1 & $0,73 b$ & $0,73 \mathrm{~b}$ & $0,77 \mathrm{a}$ & $0,80 \mathrm{a}$ & $9,02 \mathrm{c}$ & $8,87 \mathrm{ab}$ & $94,1 \mathrm{~b}$ & $98,0_{c}$ & $71,98_{d}$ & $85,32 d$ & $273,91 b$ & $259,96 b$ & $48,67 a$ & $38,33 \mathrm{~b}$ \\
\hline 300 & $3,66 \mathrm{~b}$ & $3,65 b$ & 11,0 & 11,0 & $0,74_{b c}$ & $0,73 \mathrm{~b}$ & $0,78_{a b}$ & $0,76_{a}$ & $8,70_{b d}$ & $8,91 \mathrm{ab}$ & $92,0_{a b}$ & $92,0_{d}$ & $67,28 \mathrm{df}$ & $50,55_{c}$ & $219,99_{b}$ & 223,24 b & $47,00_{a}$ & $44,67 \mathrm{ac}$ \\
\hline 350 & $3,59_{\mathrm{ac}}$ & $3,54 \mathrm{c}$ & 11,8 & 11,8 & $0,76_{a b}$ & $0,75_{\mathrm{ab}}$ & $0,81_{a b}$ & $0,80_{a}$ & $8,80_{b c d}$ & $8,88_{a b}$ & $96,6_{b}$ & $98,0_{c}$ & 78,89 cdf & $86,38_{d}$ & $281,35_{b}$ & $265,08_{b}$ & $48,33_{a}$ & $43,33 \mathrm{ab}$ \\
\hline mean & 3,55 & 3,54 & 11,2 & 11,2 & 0,76 & 0,75 & 0,79 & 0,79 & 8,91 & 8,88 & 93,1 & 93,9 & 117,84 & 125,27 & 238,81 & 228,75 & 48,33 & 42,65 \\
\hline
\end{tabular}

*Data are means of 3 repetitions. The averages followed at least by the same letter in each column not differing itself by the "t" test (p<0,05).
(Legend: HF: Hot fill, AS: Aseptic, SS: Soluble solids, TA: Titratable acidity, TS: Total sugar, WSP: Water soluble pigments, T: tannins, V: Viscosity)

A gradual decrease in $\mathrm{SO}_{2}$ content was observed throughout storage (Table 1) with a slight stability occurring from 250 days to the end of the storage time. The analysis of variance showed that the type of bottling affected $\mathrm{SO}_{2}$ content significantly $(\mathrm{F}=31.41)$. The aseptic process showed a great retention of $\mathrm{SO}_{2}$, at the time of packing. FENNEMA [6] suggests that the loss of ascorbic acid in fruits may be minimized by treatment with $\mathrm{SO}_{2}$ during processing or storage. This may explain why vitamin $\mathrm{C}$ loss followed the same pattern as that of $\mathrm{SO}_{2}$ content in cashew apple juice during storage.

Tannin content seemed to be affected by storage time in both process. Significant difference was found at times 50 and 100 days as compared to other storage times. The type of process also affected the tannin content of the samples $(\mathrm{F}=5.32)$. ANDRADE [1] reported that tannins are significantly present in the cashew apple, which favors darkening in processed product, and metabisulfite addition greatly reduces the browning of the juice.

Juice viscosity behaved differently according to bottling process (Table 1) $(\mathrm{F}=63.13)$. Samples obtained through the hot fill process did not vary significantly throughout storage time at the 5\% level, while samples obtained through the aseptic process showed significant difference at times 200 and 250 days.

Sensorial evaluation showed no linear correlation among samples at the $5 \%$ level $(p<0,05)$, implying that there was no decrease in preference for the juice bottled through either process throughout storage time. In addition to that, the values scored by the panelists (Table 2) were kept high from start to the end of storage time for both bottling processes, which suggests that storage time did not affect the preference of the panelists. GRAUMLICH, MARCY \& ADAMS [8], reported that orange juice bottled though the same processes applied did not present significant difference throughout storage time when the two processes were compared.
TABLE 2. Mean values attributed by the panelists to high pulp content cashew apple juice packed by hot fill or aseptic process during a12-moths storage period at room temperature.

\begin{tabular}{ccc}
\hline & \multicolumn{2}{c}{ Acceptance score } \\
Storage time (days) & Hot fill & Aseptic \\
\hline 0 & $7.55_{\mathrm{a}^{*}}$ & $7.55_{\mathrm{a}}$ \\
50 & $7.13_{\mathrm{a}}$ & $7.27 \mathrm{a}$ \\
100 & $7.50_{\mathrm{a}}$ & $7.07 \mathrm{a}$ \\
150 & $6.80_{\mathrm{a}}$ & $7.43_{\mathrm{a}}$ \\
200 & $7.00_{\mathrm{a}}$ & $7.03_{\mathrm{a}}$ \\
250 & $7.23_{\mathrm{a}}$ & $7.20 \mathrm{a}$ \\
300 & $6.87 \mathrm{a}$ & $6.87 \mathrm{a}$ \\
350 & $6.87 \mathrm{a}$ & $7.47 \mathrm{a}$ \\
\hline
\end{tabular}

* Means within the same column followed by the same letter are not statistically significant at the $5 \%$ level.

\section{4 - CONCLUSIONS}

Either filling process, hot fill or aseptic, were efficient in maintaining the chemical and physical-chemical characteristics of the high pulp content cashew apple juice, stored for twelve months, since $\mathrm{pH}$, soluble solids, total titratable acidity, total sugar content, and color (water soluble pigments) did not change significantly.

The juice bottled through the aseptic process presented lower viscosity than that of the hot fill process throughout storage time.

Sensory evaluation showed that physical and physical-chemical changes found in cashew apple juice, packed by either process, did not affect juice acceptance throughout storage time. 


\section{5 - REFERENCES}

[1] ANDRADE, A.R.D. Industrialization of cashew apple; literature review and field trials. In: CONGRESSO BRASILEIRO DE CIÊNCIA E TECNOLOGIA DE ALIMENTOS, v. 11, João Pessoa. 64p. 1988.

[2] ASSOCIATION OF OFFICIAL ANALYTICAL CHEMISTS. Official Methods of analyses of the Association of Official Analytical Chemists. 11 ed. 1992. 1015 p.

[3] BRACCO, A. Tropical fruit juice: conquering a place of it's own. Alimentos e Tecnologia, v. 1, n.89, p. 4-9. 1986.

[4] BRASIL. Bill n. 196, August 28, 1987. Approval of rules and quality standards for "Cashew apple juice with high pulp content”. Diário Oficial da União, Brasília. p.22, 1987 .

[5] CURL, A.L. \& TALBURT, F.W.. Deterioration in storage. In: Tressler, D. K., Joslyn, M. A. Fruit and vegetable juice processing technology. Westport, Connecticut: AVI, p. 411-445. 1961.1028 p.

[6] Fennema, O. R.. Food Chemistry. 2.ed. Zaragoza, Spain: Acribia,. 1993. 1094p.

[7] GLANTZ, S.A. Primer of biostatistics. McGraw - Hill, N. York. 1992

[8] GRAUMLICH, T.R., MARCY, J. E., ADAMS, J.P. Aseptically packaged orange juice and concentrate: a review of the influence of processing and packaging conditions on quality. Journal Agricultural Food Chemistry, v. 34, p. 402- 405, 1986.
[9] Instituto ADOLFO LUTZ. Chemical and physical methods for food analyses. 3ed. São Paulo: Normas Analíticas do Instituto Adolfo Lutz,. v. 1, 1985. 553p.

[10] MAIA, G.A., OLIVEIRA, G.S.F., TELles, P.R.S. Processing methods, stability, and packaging of dried banana. Fortaleza: Núcleo de Tecnologia Industrial do Ceará- NUTEC. 1978. 28p.

[11] MEILGAARD, M., CIVILle, G.V., CARR, B.T. Sensory Evaluation Techniques. Florida: CRC Press, 1987. 281p.

[12] NAIR, M.K., RAO, E. V. V. B., NAMBIAR, K. K. N. et al. Cashew (Anacardium occidentale L.). Kerala: Central Plantation Crops Research Institute. 1979. 169p.

[13] OLIVA, P.B., MENEZES H.C. DE., FERREIRA, V.L.P. Stability study of acerola nectar. Ciênc. Tecnol. Aliment., v. 16, n. 3, p. 228-232, 1996.

[14] PEARSON, D. Laboratory techniques for food analyses. Zaragoza, Spain: Acribia. 1976. 331p.

[15] SAS INSTITUTE, Inc. SAS user's Guide: Statistical Analysis System, Cary, N.C. 1985

[16] SIDEL, J.L., STONE, H. The role of sensory evaluation in the food industry. Food Quality and Preference, v.4, p. 65-73. 1993.

[17] SOUZA FILHO, M. DE S.M. Physical, chemical, and physical-chemical features on evaluation and industrialization of different cashew clones (Anacardium occidentale L.) 1987. 196p. Dissertação (Mestre em Tecnologia de Alimentos), Fortaleza, Universidade Federal do Ceará (UFC).

[18] STACK, A. Quality juice processing. Fruit Processing. p. 6-10. 1995. 